\title{
Efektivitas Penanaman
}

\section{Nilai Integritas pada}

\section{Siswa SD melalui Buku}

\section{Wayang Pandawa Bervisi}

\section{Antikorupsi}

SUKADARI, MAHILDA DEA KOMALASARI, DAN AHMAD MABRURI WIHASKORO

Universitas PGRI Yogyakarta

Universitas PGRI Yogyakarta

STPI Bina Insan Mulia Yogyakarta

sukadariupy@gmail.com

mahilda_dea@yahoo.com

ahmadwihaskoro@gmail.com

p-ISSN: 2477-118X

e-ISSN: 2615-7977

\section{A B S T RAK}

Penelitian ini bertujuan untuk menghasilkan buku Wayang Pandawa bervisi antikorupsi yang dapat digunakan menurut ahli 
materi dan ahli media sebagai wahana penanaman nilai integritas pada siswa sekolah dasar. Selain itu, penelitian ini juga bertujuan untuk mengetahui efektivitas penanaman nilai integritas pada siswa sekolah dasar melalui buku Wayang Pandawa bervisi antikorupsi. Penelitian ini merupakan penelitian dan pengembangan (research and development, $\mathrm{R} \& \mathrm{D})$ dengan mengacu model pengembangan 4D (four $D$ ) terdiri atas empat tahap utama yaitu: Define (Pendefinisian), Design (Perancangan), Develop (Pengembangan) dan Disseminate (Penyebaran) (Thiagarajan, Semmel, \& Semmel, 1974). Subjek pada penelitian ini adalah siswa kelas V SDN Donotirto Yogyakarta sejumlah 23 siswa. Hasil penelitian menunjukkan bahwa penanaman nilai integritas pada siswa sekolah dasar terbukti efektif melalui buku Wayang Pandawa bervisi antikorupsi.

Kata Kunci: wayang pandawa, integritas, antikorupsi, siswa sekolah dasar

\section{A B S TRACT}

This study aims to produce Wayang Pandawa book visionary anticorruption that can be used according to the matter expert and media expert as a mode for the cultivation of integrity value for elementary students. In addition, this study also aims to determine the effectiveness of cultivation of integrity value in elementary students through Wayang Pandawa book visionary anticorruption. This study was a research and development ( $R \& D)$ with reference to $4 D$ (four D) development model consisting of four development stages, i.e.: (1) define; (2) design; (3) develop; (4) Disseminate (Thiagarajan, Semmel, \& Semmel, 1974). The subjects in this study were the fifthgrade students of elementary school of Donotirto Yogyakarta, as many as 23 students. The result of the research was shown that the cultivation of integrity value in elementary students proved effective through 'Wayang Pandawa' book visionary anticorruption.

Keywords: anticorruption, elementary student, integrity, wayang pandawa 


\section{A. PENDAHULUAN}

Indonesia merupakan suatu bangsa yang besar dengan memiliki beragam potensi maupun sumber daya. Sebagai bangsa yang besar, Indonesia bercita-cita untuk menyejahterakan bangsanya. Namun bila diamati dari kondisi ekonomi masyarakat, Indonesia belum dapat dikatakan sebagai negara yang berhasil ataupun maju. Hal itu dikarenakan kesenjangan ekonomi bangsa Indonesia yang tinggi. Banyak faktor yang menyebabkan Indonesia belum berhasil menyejahterakan seluruh rakyatnya, salah satu faktornya adalah perilaku korup yang saat ini semakin masif dan sudah menjangkiti seluruh aspek kehidupan, mulai dari politik, ekonomi, sosial, budaya, dan bahkan agama. Kasus korupsi telah menjadi konsumsi media publik baik cetak maupun elektronik. Setiap hari hampir media publik tidak pernah absen menyuguhkan berita tentang korupsi.

Korupsi disebabkan oleh dua faktor, yaitu faktor eksternal dan faktor internal. Faktor internal meliputi aspek moral, sikap atau perilaku, serta sosial, sedangkan faktor eksternal penyebab korupsi bisa dilihat dari aspek ekonomi, politik, manajemen dan organisasi, hukum, serta aspek sosial. Salah satu upaya untuk mengatasi korupsi di Indonesia adalah melalui pencegahan. Selama ini, pencegahan korupsi masih belum menarik perhatian dibandingkan penindakan korupsi. Padahal pencegahan korupsi merupakan langkah awal dari penindakan korupsi. Artinya, bila pencegahan korupsi membuahkan hasil yang efektif, maka akan mengurangi penindakan korupsi. Pencegahan korupsi dilakukan dengan cara menguatkan faktor internal agar individu tidak akan tergoda untuk melakukan korupsi. Akar-akar korupsi salah satunya berawal dari rendahnya integritas diri, sehingga pengintegrasian nilai antikorupsi dapat dilakukan melalui penanaman nilai integritas. Dengan dimilikinya nilai integritas, maka individu juga dapat mengendalikan faktor eksternal agar korupsi tidak terjadi. Salah satu upaya penanaman nilai integritas dilakukan melalui jalur pendidikan. Internalisasi nilai integritas dalam pendidikan sebaiknya dilakukan sedini mungkin. 
Terkait hal di atas, banyak pihak yang berpendapat bahwa sekolah dasar merupakan wadah utama pembentukan karakter. Pembelajaran di sekolah dasar merupakan fondasi pendidikan yang efektif dalam pembentukan watak dan kepribadian, sehingga dalam pembelajaran di sekolah dasar tersebut cocok ditanamkan nilai integritas. Proses pembelajaran di sekolah dasar yang bertujuan membentuk watak warga negara agar sesuai dengan kepribadian bangsa Indonesia, kenyataanya hanyalah slogan belaka. Sekolah dasar yang dipandang dapat memegang peran penting dalam menanamkan nilai integritas sesuai dengan falsafah bangsa dan konstitusi negara Republik Indonesia, untuk saat ini hanya sampai pada domain kognitif. Hal itu dapat dilihat dari buku pegangan siswa sekolah dasar yang cenderung menekankan ranah kognitif dan sedikit porsi mengembangkan karakter siswa.

Akar dari pencegahan korupsi adalah penanaman nilai integritas perorangan. Integritas perorangan dapat ditanamkan dengan cara: 1) menanamkan nilai agama, misalnya memberikan buku kegiatan pada setiap siswa mengenai perkembangan ibadahnya sesuai dengan agama yang dianutnya; 2) menanamkan sikap disiplin pada anak, seperti disiplin dalam menghargai waktu; 3) menumbuhkan rasa percaya diri pada anak; 4) memberlakukan peraturan-peraturan serta sanksi bagi yang melanggar; 5) memprioritaskan sikap jujur dalam segala hal, termasuk pada saat ujian; 6) membiasakan sikap kerja sama dan bertanggung jawab.

Pencegahan korupsi melalui pendidikan dapat dilakukan dengan cara: 1) terintegrasi dalam mata pelajaran; 2) melalui kegiatan ekstrakurikuler; 3) pembudayaan, pembiasaan nilai dalam seluruh aktivitas dan suasana sekolah. Pencegahan korupsi secara terintegrasi dalam mata pelajaran dapat dilakukan melalui penanaman nilai-nilai integritas ke dalam materi pembelajaran, sedangkan pencegahan korupsi melalui kegiatan ekstrakurikuler dapat dilakukan melalui penanaman nilai integritas ke dalam kegiatan ekstrakurikuler, seperti pramuka, Palang Merah Remaja (PMR), karya ilmiah, dan lainnya, dimana pada kegiatan tersebut siswa diajarkan untuk hidup hemat, 
bersahaja, disiplin, jujur, dan bertanggung jawab. Pencegahan korupsi yang terakhir, yaitu melalui pembudayaan, seperti kebiasaan membuang sampah pada tempatnya, adanya kantin kejujuran, tidak terlambat masuk kelas, larangan menyontek saat ujian, serta adanya slogan-slogan pencegahan korupsi di sekolah.

Dalam penelitian ini, pencegahan korupsi melalui pendidikan dilakukan dengan cara terintegrasi dalam mata pelajaran, yaitu mengintegrasikan nilai-nilai integritas ke dalam materi pembelajaran, yaitu materi pembelajaran Wayang Pandawa yang mengacu pada muatan mata pelajaran Pendidikan Kewarganegaraan (PKn) dan Bahasa Jawa. Nilai integritas dan pencegahan korupsi merupakan muatan dari mata pelajaran PKn, sedangkan materi Wayang Pandawa merupakan muatan dari mata pelajaran Bahasa Jawa.

Dengan adanya kenyataan tersebut, peneliti bermaksud mengadakan penelitian penanaman nilai integritas pada siswa SD melalui buku Wayang Pandawa bervisi antikorupsi. Dipilihnya buku Wayang Pandawa karena wayang dapat dijadikan sebagai sarana pendidikan, terutama pendidikan karakter, sebab di dalamnya terkandung unsur-unsur pendidikan di antaranya, masalah kebenaran, keadilan, kejujuran, ketaatan, kesetiaan, kepahlawanan, spiritual, psikologi, dan filsafat segala aspek perwatakan manusia dan problematikanya (Tofani, 2013). Pada sekitar tahun 1984, di wilayah perkotaan, mereka yang lahir pada tahun 1909-an, kurang lebih 20\% gaya hidup masyarakat sangat terpengaruh oleh konsep-konsep ajaran hidup yang biasanya terdapat dalam cerita wayang. Di pedesaan, meski ada yang tidak mengetahui tentang wayang, namun lebih banyak masyarakat yang senang, tertarik dan terpengaruh oleh cerita-cerita mitologi wayang (Koentjaraningrat, 1994). Hal ini dapat dijadikan alasan kuat karena kurikulum muatan lokal bahasa Jawa di wilayah Daerah Istimewa Yogyakarta (DIY) memuat cerita wayang. Cerita wayang mulai diajarkan dari kelas I hingga kelas VI sekolah dasar dengan materi Punakawan, Pandawa, Ramayana dan Baratayuda. Keluasan materi yang diajarkan disesuaikan dengan tingkat pemahaman siswa di setiap jenjang. Dengan demikian, pembelajaran di 
sekolah dasar memiliki potensi menanamkan nilai integritas yang akan terinternalisasikan pada diri siswa melalui proses penyadaran.

Masalah yang muncul pada pembelajaran di sekolah dasar adalah: 1) adanya anggapan bahwa pencegahan korupsi merupakan tanggung jawab guru agama dan guru PKn; 2) aspek-aspek moral/ budi pekerti tidak diintegrasikan ke dalam setiap mata pelajaran; 3 ) proses pembelajaran cenderung bersifat transfer of knowledge dan tidak dilakukan praktik perilaku dan penerapan akhlak mulia dalam kehidupan siswa (Muhtadi, 2010). Melalui kegiatan ini, peneliti ingin memberikan alternatif solusi untuk mengatasi masalah-masalah tersebut dengan menggunakan pengembangan buku Wayang Pandawa bervisi antikorupsi sebagai wahana penanaman nilai integritas pada siswa sekolah dasar.

\section{Rumusan Masalah}

Rumusan masalah yang akan dijawab dalam penelitian ini:

b. Apakah buku Wayang Pandawa bervisi antikorupsi dapat digunakan sebagai wahana penanaman nilai integritas pada siswa sekolah dasar?

c. Bagaimanakah efektivitas penanaman nilai integritas pada siswa sekolah dasar melalui buku Wayang Pandawa bervisi antikorupsi?

\section{Tujuan Kajian}

Tujuan penelitian ini adalah untuk mengetahui sejauh mana buku Wayang Pandawa bervisi antikorupsi dapat digunakan sebagai wahana penanaman nilai integritas pada siswa sekolah dasar dan mengetahui efektivitas penanaman nilai integritas pada siswa sekolah dasar melalui buku tersebut.

\section{Metode Penelitian}

Metode penelitian yang digunakan dalam penelitian ini meng- 
gunakan pengembangan model 4-D (Four D). Model penelitian pengembangan 4-D merupakan metode pengembangan perangkat pembelajaran. Model ini dikembangkan oleh Thiagarajan, Semmel, \& Semmel (1974). Model ini terdiri atas 4 tahap utama yaitu: Define (Pendefinisian), Design (Perancangan), Develop (Pengembangan) dan Disseminate (Penyebaran). Model ini dipilih karena bertujuan untuk menghasilkan produk buku Wayang Pandawa bervisi antikorupsi. Produk yang dikembangkan kemudian diuji kelayakannya dengan validitas untuk mengetahui sejauh mana buku Wayang Pandawa bervisi antikorupsi dapat digunakan sebagai wahana penanaman nilai integritas pada siswa sekolah dasar, kemudian diuji efektivitas produk untuk mengetahui sejauh mana efektivitas penanaman nilai integritas pada siswa sekolah dasar melalui buku Wayang Pandawa bervisi antikorupsi.

Penelitian ini dilaksanakan di SDN Donotirto Yogyakarta pada bulan Maret tahun 2018. Subjek penelitian adalah siswa kelas V SDN Donotirto Yogyakarta yang terdiri dari 23 siswa. Teknik pengumpulan data yang digunakan dalam penelitian yaitu angket respons siswa terhadap buku Wayang Pandawa; dan angket integritas siswa. 


\section{Gambar 1. Bagan Alir Penelitian}

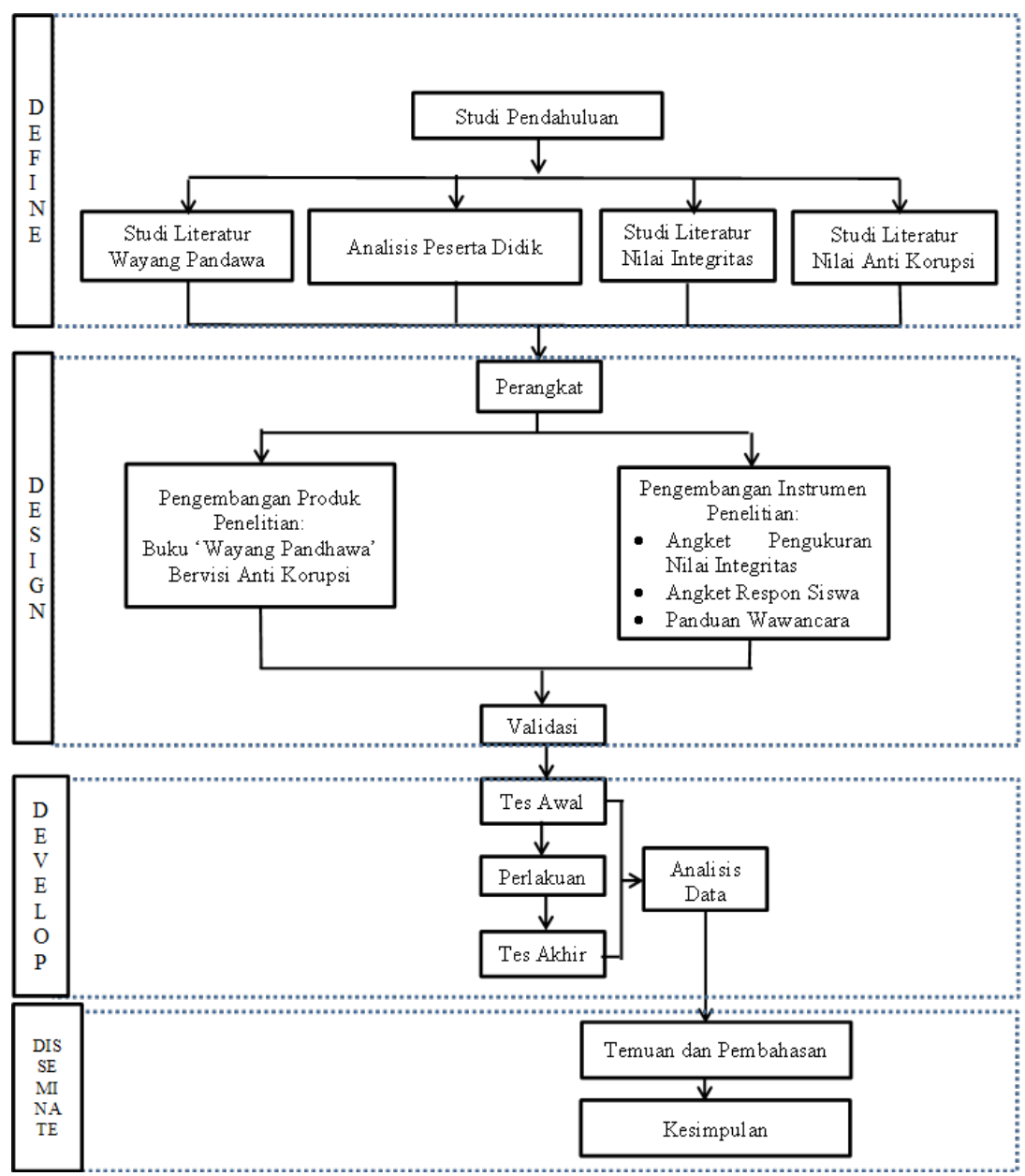

\section{1. Analisis Produk}

Analisis produk digunakan untuk mengetahui sejauh mana buku Wayang Pandawa bervisi antikorupsi dapat digunakan sebagai wahana penanaman nilai integritas pada siswa sekolah dasar. Analisis produk dilakukan oleh ahli materi dan ahli media. Langkah-langkah analisis produk sebagai berikut:

a. Mengubah penilaian dalam bentuk kualitatif menjadi kuantitatif menggunakan teknik skala bertingkat dengan ketentuan skor 5 untuk kriteria sangat baik, 4 untuk kriteria baik, 3 untuk kriteria kurang baik, 2 untuk kriteria tidak baik dan skor 
1 untuk kriteria sangat tidak baik.

b. Mengubah skor rata-rata menjadi nilai kualitatif sesuai kriteria penilaian berikut:

Tabel 1. Konversi Data Kuantitatif ke Data Kualitatif

\begin{tabular}{lll} 
Nilai & Rentang Skor (i) & Kategori \\
\hline A & $81-100$ & sangat baik \\
B & $61-80$ & Baik \\
C & $41-60$ & cukup baik \\
D & $21-40$ & kurang baik \\
E & $0-20$ & sangat kurang baik
\end{tabular}

Penelitian ini diharapkan mendapat nilai produk minimal 'B' dengan kriteria 'baik', maka produk buku Wayang Pandawa bervisi antikorupsi dapat digunakan sebagai wahana penanaman nilai integritas pada siswa sekolah dasar.

\section{2. Analisis Efektivitas}

a. Uji Prasayarat

Uji prasyarat yang harus dipenuhi adalah uji normalitas dan uji homogenitas terhadap data nilai integritas siswa sekolah dasar sebelum dan sesudah pembelajaran menggunakan buku Wayang Pandawa bervisi antikorupsi.

\section{a.1. Uji Normalitas}

Uji normalitas dalam penelitian ini menggunakan Uji Satu Sampel Kolmogorov-Smirnov dengan bantuan program IBM SPSS Statistics 21. Pengujian normalitas didasarkan pada hipotesis berikut.

$\mathrm{H}_{01}$ : sampel berasal dari populasi berdistribusi normal 
$\mathrm{H}_{\mathrm{a} 1}$ : sampel tidak berasal dari populasi berdistribusi normal

\section{a. 2. Uji homogenitas}

Uji homogenitas dalam penelitian ini dibantu dengan program IBM SPSS Statistics 21. Pengujian homogenitas didasarkan pada hipotesis sebagai berikut.

$\mathrm{H}_{02}$ : varians pada tiap kelompok sama (homogen)

$\mathrm{H}_{\mathrm{a} 2}$ : varians pada tiap kelompok tidak sama (tidak homogen)

\section{b. Uji-T Data Berpasangan}

Efektivitas penanaman nilai integritas pada siswa sekolah dasar melalui buku Wayang Pandawa bervisi antikorupsi pada penelitian ini menggunakan uji-t data berpasangan yang dinilai berdasarkan perbandingan antara nilai integritas yang diperoleh siswa sebelum dan setelah melaksanakan pembelajaran menggunakan buku Wayang Pandawa bervisi antikorupsi. Hipotesis yang digunakan adalah:

$\mathrm{H}_{03}$ : Tidak ada perbedaan nilai integritas siswa SD yang signifikan antara sebelum dan setelah pembelajaran yang menggunakan buku Wayang Pandawa bervisi antikorupsi.

$\mathrm{H}_{\mathrm{a} 3}$ : Terdapat peningkatan nilai integritas siswa SD yang signifikan antara sebelum dan setelah pembelajaran yang menggunakan buku Wayang Pandawa bervisi antikorupsi.

Efektivitas penanaman nilai integritas pada siswa sekolah dasar melalui buku Wayang Pandawa bervisi antikorupsi dapat dilihat dari rata-rata nilai integritas sebelum dan setelah pembelajaran. Apabila rata-rata nilai integritas setelah pembelajaran lebih tinggi dari pada rata-rata nilai integritas sebelum pembelajaran, maka penanaman nilai integritas pada siswa sekolah dasar terbukti efektif melalui buku Wayang Pandawa bervisi antikorupsi. 


\section{Penelitian Terdahulu}

Penelitian yang terkait dengan Wayang pernah dilakukan oleh Nurlaili, Suwignyo, dan Setyosari pada tahun 2016 yang diuraikan dalam bentuk Jurnal Pendidikan, Vol 01, No 07, Bulan Juli, Tahun 2016, Hal 1427-1437 dengan judul "Pengembangan Multimedia untuk Pengenalan Tokoh Wayang dalam Pembelajaran Bahasa Jawa". Tingkat kevalidan yang diperoleh multimedia pengenalan tokoh wayang ini mencapai $85,35 \%$ dan tingkat kepraktisan mencapai $89 \%$. Tingkat kemenarikan produk mencapai $88,15 \%$ dan tingkat keefektifan pengenalan tokoh wayang sebesar $93,2 \%$, dengan predikat sangat efektif dan dapat dipergunakan tanpa perbaikan. Keefektifan multimedia pengenalan tokoh wayang diperoleh dari banyak siswa yang mengalami peningkatan dari nilai prates ke nilai pascates. Kebanyakan siswa yang menjawab salah pada soal pengenalan tokoh prates, menjawab benar pada soal pengenalan tokoh soal pascates.

Penelitian yang terkait dengan wayang pernah dilakukan oleh Emosda tahun 2011 yang diuraikan dalam bentuk Jurnal Innovatio, Vol. X, No. 1, Januari-Juni 2011. Universitas Jambi, Indonesia. Tentang penanaman nilai-nilai kejujuran dalam menyiapkan karakter bangsa. Hasil penelitian menunjukkan bahwa dalam menyiapkan karakter bangsa, pendidik hendaklah mengerjakan tugasnya dengan rasa kasih sayang, penuh keikhlasan, kejujuran, keagamaan, dan dalam suasana kekeluargaan.

\section{Kerangka Teori}

\subsection{Wayang Pandawa}

Istilah wayang berasal dari bahasa Jawa "Wewayangan" atau "Wayangan" yang bermakna bayangan, karena penonton pertunjukan wayang dapat menyaksikannya dari belakang kelir atau hanya melihat bayangannya saja. Wayang sudah lama masuk menjadi kebudayaan di Indonesia dan diperkirakan seni pewayangan dibawa masuk oleh pedagang India (Marwanto, 2000). Wayang Indonesia telah menjadi primadona di Pulau Jawa dan Bali. Pada 7 November 
2003 lembaga PBB yang menaungi kebudayaan (UNESCO) menganugerahi wayang Indonesia sebagai Masterpiece of Oral and Intangible Heritage of Humanity (Laksono, 2012). Sebuah penghargaan terhadap wayang sebagai pertunjukan bayangan boneka tersohor dan warisan mahakarya dunia yang bernilai tinggi.

Wayang merupakan kekayaan budaya yang bernilai tinggi, karena dalam wayang terdapat berbagai macam bentuk kesenian, seperti seni sastra, seni suara, seni musik, dan seni rupa, digabungkan menjadi satu sehingga tercipta sebuah pertunjukan yang indah, menarik, dan padat makna. Bagi orang Jawa, wayang merupakan cermin dari sifat dan perilaku manusia.

Dari sekian banyak tokoh wayang, tokoh wayang yang diambil dalam penelitian ini adalah tokoh Wayang Pandawa yang merupakan tokoh wayang dengan karakter yang baik sehingga dapat dicontoh dalam sebuah pembelajaran karakter di sekolah. Istilah "Pandawa" berasal dari bahasa Sansakerta yang secara harfiah berarti anak Pandu. Pandu merupakan salah satu Raja Hastinapura dalam cerita Mahabharata. Dengan demikian, maka Pandawa merupakan putra mahkota kerajaan tersebut. Tokoh Pandawa adalah Yudistira, Bima, Arjuna, Nakula dan Sadewa.

a. Yudistira

Yudistira adalah putra sulung Prabu Pandu dengan isterinya Dewi Kunti. Yudistira memiliki nama lain yaitu Raden Wijakangka, Puntadewa, Samiaji dan Dharmaputra. Sifat dan tingkah-lakunya rajin, santun, bersahaja, jujur, lemah lembut, berbakti kepada orangtua, ikhlas memberi kepada orang lain, tekun beribadah, dan sabar.

b. Bima

Bima atau Raden Werkudara merupakan anak kedua dari Prabu Pandu dan Dewi Kunti. Bima memiliki nama lain, yaitu Werkudara, Bimasena, Bratasena, Bayusuta, Kusuma Dilaga, dan Abilawa. Sifat dan tingkah-lakunya 
rajin, jujur, pemberani, pantang menyerah, rela menolong, menghargai sesama, setya janji, berbakti kepada orangtua, menyayangi saudara, dan tidak membeda-bedakan status.

c. Arjuna

Arjuna merupakan anak ketiga dari Prabu Pandu dan Dewi Kunti yang berwajah tampan. Nama lain Arjuna di antaranya adalah Janaka, Permadi, Panduputra, Indratanaya, Kuntadi, Palguna, dan Danajaya. Arjuna seorang satria yang gemar berkelana, bertapa dan berguru menuntut ilmu. Sifat dan tingkah-lakunya halus, tenang, terampil, cekatan, rajin, cerdas, dan pemberani. Keahlian Arjuna adalah memanah.

d. Nakula

Nakula merupakan anak dari Prabu Pandu Dewanata dan Dewi Madrim. Nakula merupakan titisan dari dewa kembar Aswan. Nama lain Nakula ialah Pinten. Sifat dan tingkah-lakunya periang, jujur, setia, menyimpan rahasia, rajin, penurut, dan pemberani. Nakula memiliki ajiaji yaitu Aji Pranawajati. Aji ini membuat Nakula tidak dapat lupa akan hal apapun.

e. Sadewa

Sadewa atau Tangsen merupakan saudara kembar Nakula. Sadewa merupakan anak bungsu dari Raden Pandu. Sadewa merupakan titisan dari Dewa Aswin. Sifat dan tingkah-lakunya periang, jujur, setia, menyimpan rahasia, rajin, penurut, dan pemberani. Sadewa memiliki ingatan yang kuat karena memiliki Aji Purnamajati, dan memiliki Mantra Pangruwatan (Tofani, 2013). 


\section{2. Pencegahan Korupsi Melalui Pendidikan}

Istilah korupsi diuraikan dalam berbagai definisi, yaitu yang berkaitan dengan penyuapan, manipulasi di bidang ekonomi, serta yang menyangkut bidang kepentingan umum. Hal itu diambil dari definisi yang berbunyi, "Financial manipulations and deliction injurious to the economy are often labeled corrupt." (Hartanti, 2008). Korupsi dalam bahasa Inggris disebut corruptie, yang bermakna perbuatan curang, tindak pidana yang merugikan keuangan negara (Subekti \& Tjitrosoedibio, 1973), sehingga korupsi merupakan suatu perbuatan yang jahat dan merusak, serta bersifat amoral dan menyangkut jabatan atau aparatur pemerintah, yang berkaitan dengan penyelewengan kekuasaan dalam jabatan karena pemberian, menyangkut faktor ekonomi dan politik dan penempatan keluarga atau golongan ke dalam kedinasan di bawah kekuasaan jabatan. Dengan demikian, korupsi dapat diartikan sebagai sebuah bentuk tindakan yang bertujuan untuk menguntungkan diri sendiri, orang lain ataupun korporasi, dengan demikian perilaku korupsi harus dicegah sedini mungkin.

Pencegahan korupsi perlu dilakukan sedini mungkin. Ada beberapa faktor yang memicu perilaku korupsi. Faktor pemicu tindak korupsi bersifat internal dan eksternal. Faktor internal bisa meliputi sifat tamak yang ada dalam diri manusia, moral yang tidak kuat menahan godaan di depan mata, dan penghasilan yang kurang memadai, sedangkan penyebab eksternal adalah situasi lingkungan atau adanya peluang, dan kesempatan yang sangat mendukung. Pencegahan korupsi melalui jalur pendidikan lebih efektif, karena pendidikan merupakan proses perubahan sikap mental yang terjadi pada diri seseorang, dan melalui jalur pendidikan, pencegahan korupsi lebih tersistem serta mudah terukur.

Pencegahan korupsi perlu diterapkan untuk setiap individu agar dapat mengatasi faktor internal penyebab korupsi sehingga harapannya korupsi tidak terjadi. Nilai-nilai yang dapat ditumbuhkan untuk pencegahan korupsi, yaitu kejujuran, kepedulian, kemandirian, kedisiplinan, pertanggungjawaban, kerja keras, kesederhanaan, 
keberanian, dan keadilan. Nilai-nilai inilah yang akan mendukung prinsip-prinsip antikorupsi untuk dapat dijalankan dengan baik (Kemendikbud, 2011).

Sekolah dapat melakukan tiga hal untuk berpartisipasi dalam gerakan antikorupsi. Pertama, memrogram pendidikan yang mampu menumbuhkan kepedulian yang tulus, membangun penalaran obyektif dan mengembangkan perspektif universal pada individu. Kedua, memrogram pendidikan yang mengarah pada pembentukan kualitas pribadi individu yang konsekuen dan kokoh dalam keterlibatan politiknya. Ketiga, memrogram pendidikan yang berorientasi penanaman integritas guna menumbuhkan keberanian individu dalam mempertahankan kejujuran dan kesederhanaan sebagai prinsip dasar keterlibatan politik. Implementasi pendidikan antikorupsi di sekolah bisa menggunakan strategi eksklusif yang menyajikan pendidikan antikorupsi sebagai sebuah mata pelajaran namun tidak bersifat kurikuler atau dalam kurikulum muatan lokal (institusional). Dalam penelitian ini, visi antikorupsi lebih ditekankan pada penanaman karakter integritas.

Pencegahan korupsi melalui pendidikan merupakan usaha sadar dan terencana untuk mewujudkan proses pendidikan yang kritis terhadap nilai-nilai antikorupsi. Muhammad Nuh dalam Wibowo (2013) berpendapat bahwa program pendidikan antikorupsi bertujuan untuk menciptakan generasi muda yang bermoral baik dan berperilaku antikorupsi.

Sumiarti dalam Mukodi \& Burhanuddin (2014), pendidikan antikorupsi merupakan tindakan untuk mengendalikan dan mengurangi korupsi berupa keseluruhan upaya untuk mendorong generasi mendatang agar mengembangkan sikap secara tegas menolak segala bentuk korupsi.

Tujuan pencegahan korupsi untuk membangun karakter teladan agar anak juga dapat menjadi promotor pemberantas korupsi. Untuk mewujudkan pendidikan antikorupsi, pendidikan di sekolah harus diorientasikan pada tataran moral action agar siswa tidak hanya berhenti pada kompetensi (competence) saja, tetapi sampai memiliki 
kemauan (will), dan kebiasaan (habit) dalam mewujudkan nilai-nilai kehidupan sehari-hari. Untuk mendidik moral anak sampai pada tataran moral action diperlukan tiga proses pembinaan yang berkelanjutan mulai dari proses moral knowing, moral feeling, hingga sampai pada moral action. Ketiganya harus dikembangkan secara terpadu dan seimbang. Dengan demikian diharapkan potensi siswa dapat berkembang secara optimal, baik pada aspek kecerdasan intelektual, yaitu memiliki kecerdasan, kemampuan membedakan yang baik-buruk, benar-salah, serta menentukan mana yang bermanfaat. Kecerdasan emosional, berupa kemampuan mengendalikan emosi, menghargai dan mengerti perasaan orang lain, dan mampu bekerja dengan orang lain.

Pendidikan moral harus memberikan perhatian pada ketiga komponen karakter yang baik (components of the good character) yaitu, pengetahuan tentang moral (moral knowing), perasaan tentang moral (moral feeling), dan perbuatan bermoral (moral action). Moral knowing berkaitan dengan moral awareness, knowing moral values, perspective taking, moral reasoning, decision making, dan self-knowledge. Moral feeling berkaitan dengan conscience, self-esteem, empathy, loving the good, self-control, dan humility. Sedangkan moral action merupakan perpaduan antara moral knowing dan moral feeling yang diwujudkan dalam bentuk kompetensi (competence), keinginan (will), dan kebiasaan (habit). (Komalasari \& Wihaskoro, 2016).

Ketiga komponen tersebut perlu diperhatikan dalam kaitannya dengan pendidikan antikorupsi yang di dalamnya mencakup perilaku antikorupsi agar siswa memahami, merasakan, dan mempraktikannya dalam kehidupan sehari-hari.

Berdasarkan dari beberapa pendapat para ahli pencegahan korupsi melalui pendidikan adalah usaha sadar dan terencana untuk mewujudkan proses belajar-mengajar yang kritis terhadap nilai-nilai antikorupsi yang bertujuan untuk menciptakan generasi muda yang bermoral baik dan berperilaku antikorupsi. 


\section{3. Integritas}

Integritas berasal dari bahasa Latin yang berarti utuh, tidak tersentuh, lengkap, dan menyeluruh. Integritas merupakan salah satu karakter yang menyusun strength of courage. Integritas sebagai karakter disusun oleh virtue honesty dan virtue authenticity (Peterson \& Selignman, 2004). Cakupan integritas lebih luas daripada nilai kejujuran, meskipun ketika mendengar ungkapan 'individu yang berintegritas', umumnya langsung terpikir seorang yang jujur (Carter, 1996).

Integritas merupakan skema dari pendekatan identitas seseorang dimana terfokus pada agen moral dalam diri seseorang tersebut. Ada tiga hal yang dapat mengidentifikasikan integritas. Pertama, integritas adalah sebuah bentuk loyalitas, yaitu adanya keteguhan hati seseorang untuk memegang prinsip dan nilai moral. Kedua, integritas bukan perkataan semata, melainkan cerminan tindakan yang sejalan dengan prinsip dan nilai moral. Dan ketiga, integritas bukan sekadar bertindak sejalan dengan suatu prinsip atau nilai, namun juga prinsip atau nilai yang dibenarkan secara moral. Sedangkan, integritas moral adalah rasa keutuhan dan keseimbangan dalam diri individu dalam meyakini moral yang dianut, konsisten dalam perilaku, dan malu jika melanggar (William dalam Edgar \& Pattison, 2011; Wisesa, 2011; Carter dalam Paul \& Olson, 2002).

Identifikasi integritas berupa kata hati, moral yang akuntabel, komitmen, dan konsisten dari seseorang yang mana antara perilaku yang ditunjukkannya berasal dari nilai-nilai dan prinsip-prisip tertentu (Becker dalam Wisesa, 2011). Integritas merupakan suatu bentuk dari identitas moral, dimana hal tersebut relatif tetap dan stabil di setiap saat. Identitas moral tersebut berperan penting terhadap regulasi diri (self-regulation) yang terkait dalam sikap dan perilaku moral (Schlenker dalam Dunn, 2009).

Integritas merupakan sikap menghormati atau tidak melanggar komitmen dan janji yang dibuatnya sendiri, karena melanggar komitmen dan janji akan mendatangkan rasa malu terhadap diri sendiri. Integritas merupakan sikap dominan dari konsistensi dan 
keteguhan dalam menjunjung tinggi nilai-nilai luhur dan keyakinan. Suatu konsep yang menunjukkan konsistensi antara tindakan dengan kandungan nilai dan prinsip.

Individu yang memiliki integritas bersedia menanggung konsekuensi dari komitmen dan janji yang telah dibuatnya, meskipun konsekuensi tersebut sulit dilakukan maupun tidak menyenangkan baginya (Carter, 1996). Integritas juga didefinisikan sebagai kondisi yang terjadi ketika individu mampu menerima serta bertanggung jawab terhadap perasaan, niat, komitmen dan perilaku, termasuk mengakui kondisi itu kepada orang lain bila diperlukan, serta kemampuan mengkomunikasikan perasaan yang dialami, disadari, dan diakui (Rogers, 1961). Integritas merupakan konsistensi pikiran, emosi, kata-kata, serta tindakan yang stabil sepanjang waktu dan situasi (Blasi, 2004; Palanski \& Yamarino, 2007).

\section{B. PEMBAHASAN}

\section{Analisis Produk}

Hasil evaluasi produk yang dilakukan oleh ahli materi ditunjukkan oleh Tabel 2. Hasil evaluasi produk yang dilakukan oleh ahli media ditunjukkan oleh Tabel 3.

Tabel 2. Hasil Evaluasi Buku 'Wayang Pandawa' oleh Ahli Materi

\begin{tabular}{clcl}
\hline No & Aspek Penilaian & Skor & Kategori \\
\hline 1 & Kelayakan isi & 91,4 & Sangat Baik \\
\hline 2 & Penyajian & 93,3 & Sangat Baik \\
\hline 3 & Kebahasaan & 90 & Sangat Baik \\
\hline & Skor Rata-Rata & 91,6 & Sangat Baik
\end{tabular}

Tabel 3. Hasil Evaluasi Buku 'Wayang Pandawa' oleh Ahli Media

\begin{tabular}{clcl}
\hline No & Aspek Penilaian & Skor & Kategori \\
\hline 1 & $\begin{array}{l}\text { Tampilan dan } \\
\text { Konten }\end{array}$ & 90 & Sangat Baik \\
\hline 2 & Format Penulisan & 90 & Sangat Baik \\
\hline & Skor Rata-Rata & 90 & Sangat Baik
\end{tabular}


Berdasarkan Tabel 2 diketahui bahwa skor rata-rata hasil evaluasi buku Wayang Pandawa berdasarkan penilaian ahli materi berada pada kategori sangat baik. Berdasarkan Tabel 3 diketahui bahwa skor rata-rata hasil evaluasi buku Wayang Pandawa berdasarkan penilaian ahli media berada pada kategori sangat baik. Hal itu mengindikasikan bahwa produk buku Wayang Pandawa bervisi antikorupsi dapat digunakan sebagai wahana penanaman nilai integritas pada siswa sekolah dasar.

\section{Analisis Efektivitas}

\section{1.Uji Prasyarat}

Uji prasyarat penelitian yaitu uji normalitas dan uji homogenitas yang dilakukan dengan bantuan program IBM SPSS Statistics 21. Hasil uji normalitas ditunjukkan pada Tabel 4. Hasil uji homogenitas ditunjukkan pada Tabel 5.

Tabel 4. Uji Normalitas

One-Sample Kolmogorov-Smirnov Test

\begin{tabular}{|c|c|c|c|}
\hline & & Sebelum & Setelah \\
\hline \multirow[t]{2}{*}{$\mathrm{N}$} & & 23 & 23 \\
\hline & Mean & 167.61 & 189.48 \\
\hline \multirow[t]{2}{*}{ Normal Parameters ${ }^{\mathrm{a}, \mathrm{b}}$} & Std. Deviation & 4.510 & 5.008 \\
\hline & Absolute & .206 & .107 \\
\hline \multirow{2}{*}{ Most Extreme Differences } & Positive & .206 & .094 \\
\hline & Negative & -.107 & -.107 \\
\hline \multirow{2}{*}{ Kolmogorov-Smirnov Z } & & .987 & .513 \\
\hline & & .284 & .955 \\
\hline Asymp. Sig. (2-tailed) & & & \\
\hline
\end{tabular}

a. Test distribution is Normal.

b. Calculated from data. 
Tabel 5. Uji Homogenitas

\begin{tabular}{|c|c|c|c|}
\hline \multicolumn{4}{|c|}{ Test of Homogeneity of Variances } \\
\hline Skor & & & \\
\hline Levene Statistic & df1 & df2 & Sig. \\
\hline .541 & 1 & 44 & .466 \\
\hline
\end{tabular}

Berdasarkan Tabel 4 dapat dilihat bahwa nilai integritas sebelum pembelajaran memiliki skor Kolmogorov-Smirnov Z 0,987 dengan Sig. 0,284; dan setelah pembelajaran memiliki skor KolmogorovSmirnov Z 0,513 dengan Sig. 0,955. Hal ini menunjukkan bahwa kedua kelompok data berasal dari populasi berdistribusi normal, sehingga uji prasyarat normalitas telah terpenuhi.

Berdasarkan Tabel 5 dapat dilihat bahwa skor Levene Statistic 0,541 dengan Sig. 0,466. Hal ini menunjukkan bahwa varian pada kedua kelompok data adalah sama (homogen), sehingga uji prasyarat homogenitas telah terpenuhi.

\section{2.Uji-T Data Berpasangan}

Hasil uji efektivitas penanaman nilai integritas pada siswa sekolah dasar melalui buku Wayang Pandawa bervisi antikorupsi ditunjukkan pada Tabel 6.

Tabel 6. Uji-T Data Berpasangan

\begin{tabular}{|c|c|c|c|c|c|c|c|c|c|}
\hline \multicolumn{10}{|c|}{ Paired Samples Test } \\
\hline & & \multicolumn{5}{|c|}{ Paired Differences } & \multirow[t]{2}{*}{$\mathrm{t}$} & \multirow[t]{2}{*}{$\mathrm{df}$} & \multirow{2}{*}{$\begin{array}{l}\text { Sig. } \\
\text { (2-tailed) }\end{array}$} \\
\hline & & \multirow[t]{2}{*}{ Mean } & \multirow[t]{2}{*}{$\begin{array}{l}\text { Std. } \\
\text { Devi- } \\
\text { ation }\end{array}$} & \multirow[t]{2}{*}{$\begin{array}{l}\text { Std. } \\
\text { Error } \\
\text { Mean }\end{array}$} & \multicolumn{2}{|c|}{$\begin{array}{l}95 \% \text { Confidence } \\
\text { Interval of the } \\
\text { Difference }\end{array}$} & & & \\
\hline & & & & & Lower & Upper & & & \\
\hline $\begin{array}{l}\text { Pair } \\
1\end{array}$ & $\begin{array}{l}\text { Setelah - } \\
\text { Sebelum }\end{array}$ & 21.870 & 7.111 & 1.483 & 18.794 & 24.945 & 14.748 & 22 & .000 \\
\hline
\end{tabular}

Berdasarkan Tabel 6 dapat dilihat bahwa skor uji-t 14,748 dengan Sig. 0,000. Hal ini menunjukkan bahwa terdapat pening- 
katan nilai integritas siswa SD yang signifikan antara sebelum dan setelah pembelajaran yang menggunakan buku Wayang Pandawa bervisi antikorupsi. Guna mendukung efektivitas penanaman nilai integritas pada siswa sekolah dasar melalui buku Wayang Pandawa bervisi antikorupsi, maka dilakukan pengukuran respons siswa. Respon siswa terhadap buku Wayang Pandawa ditunjukkan oleh Tabel 7.

Tabel 7. Respons Siswa terhadap Buku Wayang Pandawa

\begin{tabular}{clcl}
\hline No & Aspek Penilaian & Skor & Kategori \\
\hline 1 & Kelayakan isi & 91,3 & Sangat Baik \\
\hline 2 & Penyajian & 89,1 & Sangat Baik \\
\hline 3 & Kebahasaan & 82,6 & Sangat Baik \\
\hline 4 & Tampilan & 85,5 & Sangat Baik \\
\hline 5 & Karakteristik & 95,7 & Sangat Baik \\
\hline & Skor Rata-Rata & 88,8 & Sangat Baik
\end{tabular}

Berdasarkan Tabel 7 diketahui bahwa skor rata-rata respons siswa terhadap buku Wayang Pandawa berada pada kategori sangat baik.

Berdasarkan hasil uji-t data berpasangan dan respons siswa terhadap buku Wayang Pandawa mengindikasikan bahwa penanaman nilai integritas pada siswa sekolah dasar terbukti efektif melalui buku Wayang Pandawa bervisi antikorupsi.

\section{PEMBAHASAN}

Hasil pengujian yang diperoleh dalam penelitian ini menunjukkan bahwa penanaman nilai integritas pada siswa sekolah dasar terbukti efektif melalui buku Wayang Pandawa bervisi antikorupsi. Fokus utama penelitian pada kelas 5 SD Donotirto, yaitu untuk menanamkan nilai integritas siswa.

Studi pendahuluan mengungkapkan rendahnya integritas siwa 
kelas 5 SDN Donotirto ini ditunjukkan dengan adanya indikasi pada perilaku siswa berikut: 1) banyaknya siswa yang menyontek saat ujian; 2) banyaknya siswa yang datang terlambat masuk kelas; 3 ) banyaknya siswa yang membolos pada saat pembelajaran; 4) banyaknya siswa yang tidak jujur saat membayar kantin kejujuran. Peneliti menggunakan buku Wayang Pandawa sebagai wahana penanaman nilai integritas siswa. Nilai integritas siswa SDN Donotirto yang semula rendah, menjadi lebih baik seiring mendapatkan pembelajaran melalui buku Wayang Pandawa bervisi antikorupsi. Berikut ini adalah faktor-faktor yang memengaruhi efektivitas penanaman nilai integritas pada siswa sekolah dasar melalui buku Wayang Pandawa bervisi antikorupsi:

a. Tokoh wayang pandawa sangat cocok dijadikan sebagai wahana pendidikan antikorupsi karena dalam cerita tersebut terdapat nilai-nilai luhur, budi pekerti, akhlak mulia yang berakar dari ajaran agama. Banyak teladan yang bisa dipetik dari berbagai tokoh wayang. Terdapat tokoh dengan sifat terpuji yang dapat dijadikan teladan bagi siswa. Terdapat pula tokoh dengan sifat tercela yang dapat diantisipasi siswa, agar dapat menghindari sifat tercela. Sifat-sifat wayang tersebut dapat menjadi contoh untuk siswa, sikap yang terpuji dapat ditiru oleh siswa, dan sifat yang tercela dapat dihindari siswa.

b. Pengenalan tokoh wayang kepada siswa sekolah dasar penting untuk dilakukan demi menjaga kebudayaan Indonesia agar tidak tergerus globalisasi. Wayang merupakan salah satu budaya bangsa yang perlu dilestarikan karena di dalam cerita wayang terdapat banyak nasihat yang perlu diturunkan dan dicontohkan kepada generasi penerus bangsa.

c. Pendidikan antikorupsi menggunakan buku Wayang Pandawa di kelas 5 SDN Donotirto mampu menghasilkan pembelajaran yang aktif, kreatif, efektif, dan inovatif. Siswa menjadi fokus dan termotivasi untuk lebih memerhatikan penyampaian cerita Wayang Pandawa. Melalui penerapan buku ini, 
siswa memeroleh pembelajaran yang bermakna karena siswa tidak hanya diterangkan menggunakan metode ceramah dan mencatat, tapi siswa bisa mengambil pesan moral melalui pemberian contoh dalam kisah pewayangan.

d. Dari sekian banyak tokoh wayang, tokoh wayang yang diambil dalam penelitian ini adalah tokoh Wayang Pandawa yang merupakan tokoh wayang dengan karakter yang baik sehingga dapat dicontoh dalam sebuah pembelajaran antikorupsi di sekolah. Sifat kasih sayang, sabar, bertanggung jawab, jujur, dan sifat baik lainnya ada pada diri tokoh Wayang Pandawa. Pandawa selalu menang dalam melawan kejahatan, karena kelima tokoh pandawa memiliki sifat yang baik. Karakter tokoh Wayang Pandawa menjadi tuntunan dalam pengembangan karakter antikorupsi.

e. Meningkatnya integritas siswa juga disebabkan oleh pengemasan karakter dalam buku Wayang Pandawa. Mengemas wa-yang secara menarik dan sesuai dengan perkembangan zaman, pada akhirnya menjadi kunci keberhasilan buku Wayang Pandawa bervisi antikorupsi. Karena melalui pengemasan itulah, selain siswa senang dalam membacanya, siswa juga akan mudah membayangkan alur cerita dan dapat mengambil intisari cerita dengan mudah pula (Muqoddas, 2014). Selain itu, wayang harus dikemas dengan karakter yang digemari anak-anak zaman sekarang. Pengemasan karakter buku Wayang Pandawa hasil pengembangan produk terlihat pada Gambar 2 dan Gambar 3. 
Gambar 2. Kemasan buku Wayang Pandawa yang dibuat menarik.

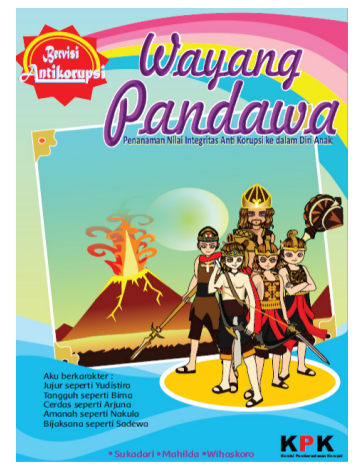

Gambar 3. Penggambaran tokoh Wayang Pandawa dikemas menarik.

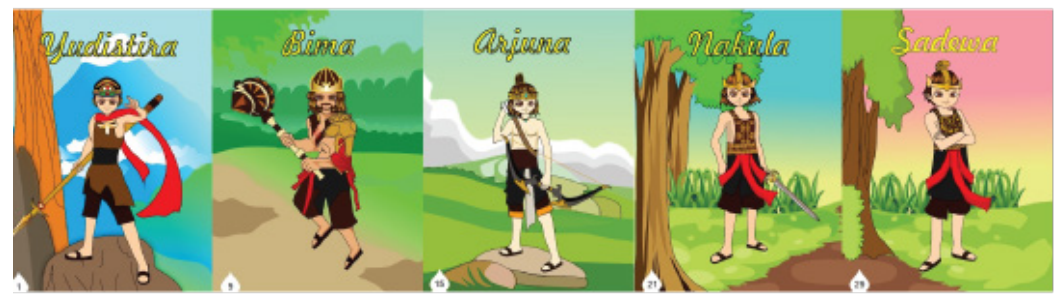

\section{PENUTUP}

\section{Simpulan}

Berdasarkan hasil penelitian dan pembahasan maka dapat diambil kesimpulan bahwa: (1) buku Wayang Pandawa bervisi antikorupsi dapat digunakan sebagai wahana penanaman nilai integritas pada siswa sekolah dasar; (2) penanaman nilai integritas pada siswa sekolah dasar terbukti efektif melalui buku Wayang Pandawa bervisi antikorupsi.

Nilai-nilai budaya dan budi pekerti luhur yang disampaikan melalui pertunjukan wayang, lebih mudah diterima. Melalui pendekatan budaya, upaya pencegahan korupsi bisa dilakukan melalui pendidikan. 


\section{Temuan}

Temuan dari penelitian ini yaitu:

a. Pendidikan antikorupsi bisa ditanamkan melalui penanaman nilai integritas pada siswa sekolah dasar.

b. Pendidikan antikorupsi bisa ditanamkan melalui literasi. Hal itu disebabkan literasi penting karena memberikan imbas besar dan langsung bagi masyarakat. Hal itu juga disampaikan oleh Sujanarko (Rifa'i, 2017) bahwa pemberdayaan komunitas literasi merupakan upaya pencegahan korupsi. Gerakan literasi penting karena memberikan imbas besar bagi masyarakat.

\section{Saran}

Berdasarkan kesimpulan dari hasil penelitian, dapat dirumuskan beberapa saran sebagai berikut.

a. Menggalakkan gerakan literasi antikorupsi.

b. Memberdayakan komunitas literasi dalam pemberantasan korupsi.

c. Mencegah korupsi melalui budaya literasi.

\section{E. REFERENSI}

Blasi, A. 2004. Moral functioning: Moral understanding and personality. In D.K. Lapsey \& D. Narvaez, Moral development, self and indentity (pp. 335-348). Lawrence Erlbaum Associates. New Jersey.

Carter, S. 1996. Integrity. Basic Books, A Division of Harper Collins Publishers. New York.

Dunn, C. P. 2009. Integrity matters. International Journal of Leadership Studies, 5 iss. 2. United Stated of America.

Edgar, A. \& Pattison, S. 2011. Integrity and the moral complexity of professional practice. Nursing Philosophy 12: 99-106. 
Emosda. 2011. Penanaman nilai-nilai kejujuran dalam menyiapkan karakter bangsa. Jurnal Innovatio, X (1): 151-166.

Hartanti, E. 2008. Tindak Pidana Korupsi. Sinar Grafika. Jakarta

Kemendikbud. (2011). Pendidikan Antikorupsi untuk Perguruan Tinggi. https://acch.kpk.go.id/id/buku-antikorupsi/perguruantinggi/pendidikan-antikorupsi-untuk-perguruan-tinggi. 23 April 2018 (15:41).

Koentjaraningrat. 1994. Kebudayaan Jawa. Balai Pustaka. Jakarta Komalasari, M. D., \& Wihaskoro, A. M. 2016. Pembelajaran Matematika Realistik yang Terintegrasi Nilai Karakter dan Kearifan Lokal untuk Siswa SD. Prosiding Seminar Nasional PGSD UPY dengan Tema Model Pembelajaran Inovatif Berbasis Kearifan Lokal untuk Mewujudkan Pendidikan Karakter Berkualitas. Universitas PGRI Yogyakarta: 251-263.

Laksono, A. 2012. Sertifikasi UNESCO Bukti Pengakuan Dunia. https://kebudayaan.kemdikbud.go.id/sertifikasi-unesco-buktipengakuan-dunia/. 29 April 2018 (05:04).

Marwanto. 2000. Apresiasi Wayang. Cendrawasih. Surakarta Muhtadi, A. 2010. Strategi implementasi pendidikan budi pekerti yang efektif di sekolah. Dinamika Pendidikan-Majalah Ilmu Pendidikan, 1, 30-39.

Mukodi, \& Burhanuddin, A. 2014. Pendidikan Anti Korupsi: Rekonstruksi Interpretatif dan Aplikatif di Sekolah. Aura Pustaka. Yogyakarta.

Muqoddas, B. 2014. Panduan Pendidikan Antikorupsi. Esensi. Jakarta.

Nurlaili, A. F., Suwignyo, H., \& Setyosari, P. 2016. Pengembangan Multimedia Untuk Pengenalan Tokoh Wayang Dalam Pembelajaran Bahasa Jawa. Jurnal Pendidikan, 1(7): 1427-1437.

Palanski, M.E., \& Yammarino, F.J. 2007. Integrity and leadership: Clearing the conceptual confusion. European Management Journal, 25(3), 171-184.

Paul, P. J., \& Olson, J. C. 2002. Consumer Behavior and Marketing. McGraw-Hill. New York. 
Peterson, C., \& Selignman, M.E. 2004. Integrity. In Character strengths and virtues: A handbook and classification (pp. 249271). Oxford University Press. Oxford.

Rifa'I, B. (2017, April 23). Dukung Literasi Antikorupi, KPK Sumbang 2.500 Buku ke TBM di Serang. https://news.detik.com/ berita/d-3482101/dukung-literasi-antikorupi-kpk-sumbang2500-buku-ke-tbm-di-serang. 23 April 2018 (15:21).

Rogers, C.R. 1961. On becoming a person: A therapist's view of psychotherapy. Houghton Mifflin. Boston.

Subekti, R., \& Tjitrosoedibio, R. 1973. Kamus Hukum. Pradnya Paramita. Jakarta

Thiagarajan, S., Semmel, D., S., \& Semmel, M., I. 1974. Instructional Development for Training Teachers of Exceptional Children. University of Minnesota. Minnesota

Tofani, M., A. 2013. Mengenal Wayang Kulit Purwa. Pustaka Agung Harapan. Surabaya

Wibowo, A. 2013. Pendidikan Karakter Berbasis Sastra. Pustaka Belajar. Yogyakarta.

Wisesa, A. L. 2011. Pengaruh Exercised Responsibility, Pengalaman, Otonomi, dan Ambiguitas Peran terhadap Kinerja Auditor di Semarang. Skripsi. Universitas Diponegoro Semarang. Semarang. 
